\title{
Rainstorm effects on the biocontrol efficacy of the decay fungus Chondrostereum purpureum against birch sprouting in boreal forests
}

\author{
Leena Hamberg $^{1}$ (D) Veli-Matti Saarinen ${ }^{2} \cdot$ Markku Rantala $^{1} \cdot$ Jarkko Hantula $^{1} \cdot$ Pekka Seiskari $^{3} \cdot$ Timo Saksa $^{2}$
}

Received: 15 January 2020 / Revised: 2 March 2020 / Accepted: 22 March 2020 / Published online: 2 April 2020

(C) The Author(s) 2020

\begin{abstract}
In forest regeneration areas, alongside roads and railways, under electric power lines and above gas pipe lines, there is a need for regular sprout control. A biocontrol method against broadleaved sprouting with formulations including the decay fungus Chondrostereum purpureum (Pers. Ex Fr.) Pouzar has been shown to be effective. Yet, heavy rain during spreading of this fungal inoculum on freshly cut stumps may affect the efficacy of the treatment, i.e., stump mortality during the following years. Thus, we performed an experiment where freshly cut birch stump surfaces (Betula pendula Roth and Betula pubescens Ehrh.) were treated with fungal inoculum under heavy irrigation and without it. Furthermore, two different adjuvants which aimed to fix the fungal inoculum to freshly cut stumps during irrigation and to protect against solar radiation were tested. Our results revealed that the artificial rainstorm treatment caused a delay in the efficacy of $C$. purpureum, but after three growing seasons, there was no significant difference in the mortality of birch stumps treated under irrigation or without it (stump mortalities 74 and $86 \%$, respectively). Adjuvants did not improve the efficacy in stumps treated under irrigation nor in those treated without irrigation.
\end{abstract}

\section{Key Points}

- Heavy rain delayed the sprout control efficacy of a fungus Chondrostereum purpureum.

- Final efficacy of formulations was the same in wet and dry conditions.

- No additional adjuvants are needed to improve formulations.

Keywords Sprout control $\cdot$ Formulation, adjuvant, stump mortality $\cdot$ Betula

\section{Introduction}

In Finland, ca. 58 million euros are used annually for young stand management operations in forest regeneration areas (Natural Resources Institute Finland 2018). In most cases, the purpose of young stand management is to control

Leena Hamberg

leena.hamberg@luke.fi

1 Natural Resources Institute Finland, Latokartanonkaari 9, FI-00790 Helsinki, Finland

2 Natural Resources Institute Finland (Luke), Juntintie 154, FI-77600 Suonenjoki, Finland

3 Verdera Ltd, P.O. Box 5, Kurjenkellontie 5 B, FI-02270 Espoo, Finland competition between cultivated conifer species and naturally grown broadleaved trees. In addition, further costs arise from regular cuttings of brushwood along roads and railways as well as under electrical power lines. Mechanical cutting with a clearing saw is the most common method for sprout removal, but associated with vigorous re-sprouting (de Jong 2000; Wall 1990), and therefore, cutting operations should be repeated regularly, which increases management costs (Uotila 2017).

In order to avoid repeated cuttings, a considerable effort has been made to develop a biological sprout control method (Becker et al. 2005; Bellgard et al. 2014; Hamberg and Hantula 2016, 2018; Hamberg et al. 2014, 2015, 2017) for boreal and temperate vegetation zones where the biocontrol agent Chondrostereum purpureum (Pers. ex Fr.) Pouzar is common (Erikson and Ryvarden 1973; Ramsfield et al. 1999; Vartiamäki et al. 2008). C. purpureum is usually a 
saprophytic or parasitic pioneer species occurring especially on deciduous stumps, branches, and trunks. It may also cause silver leaf disease in fruit trees, but is able to infect them only through freshly wounded branches, stems, or roots (Becker et al. 2005; Butler and Jones 1949; de Jong 2000; Erikson and Ryvarden 1973; Gosselin et al. 1999; Hamberg et al. 2017). The fungus occurs sometimes also in conifers (Etheridge and Morin 1963; Ramsfield et al. 1996) but is not known to cause diseases in them (Gosselin et al. 1995).

As a biocontrol agent, C. purpureum is capable of preventing sprouting of cut stumps after it is spread as an inoculum (typically small segments of hypha diluted with water or gel-based product) on freshly cut stumps (Bellgard et al. 2014; Hamberg et al. 2015). Usually, within one to three growing seasons after the treatment, the fungus can penetrate towards roots (Hamberg et al. 2017), decay wood material, and finally kill a host tree (Hamberg and Hantula 2018; Wall 1986, 1991). This method is efficient in many broadleaved trees (Becker et al. 2005; Hamberg and Hantula 2016, 2018; Hamberg et al. 2015) but harmless for healthy nontarget trees (Gosselin et al. 1999). For example, in different birch species and alder, mortalities of treated stumps have been between 80 and 100\% (Becker et al. 2005; Hamberg and Hantula 2018), and in European aspen ca. 80\% (Hamberg and Hantula 2016).

Investigations on $C$. purpureum as a biocontrol agent have usually been performed in dry and sunny weather or during a very slight rain (Hamberg and Hantula 2016, 2018, 2020; Hamberg et al. 2015). Only minor effects due to such rains before and after the treatment have been observed (decrease and increase in birch stump mortality, respectively), but even if noticed, they have disappeared after two growing seasons (Hamberg and Hantula 2020; Vartiamäki et al. 2009). Thus, the outcome of possible rainstorms during the cutting and treatment of stumps is unknown. Such information is, however, obligatory for possible practical applications, since fungal inoculum is spread on freshly cut stumps as a water suspension (Hamberg and Hantula 2018), which may be prone to heavy rain washing away inoculum from the stump surface and reducing the efficacy of treatment if compared with one performed in sunny weather.

Earlier studies indicate that the performance of C. purpureum may be significantly enhanced by formulations improving fungal growth conditions (Harper et al. 1999; Lygis et al. 2012). One option would be to use adjuvants to increase the stability of $C$. purpureum inoculum on freshly cut stump surfaces. Adjuvants are formulation additives aimed to increase the effectiveness of the control agent (Calvo-Garrido et al. 2019; Larena et al. 2010): they may act by various mechanisms, such as enabling the spray to stick better by wetting the surface, preventing or accelerating the spray drying, increasing spray absorption, or enabling more uniform spreading of the spray over the surface (improved coverage) (Boyette 2006; Pacanoski 2015).
In this study, we tested a hypothesis stating that heavy rain would decrease the efficacy of $C$. purpureum treatment (i.e., mortality of broadleaved stumps). We also evaluated whether fixing the fungal inoculum on cut stump surfaces by adjuvants would increase the treatment efficacy since rain is one of the most detrimental issues for herbicide performance (Pacanoski 2015).

\section{Material and methods}

\section{Field experiments}

The experiment was performed in two medium-fertile forest regeneration areas of Norway spruce (Picea abies (L.) H. Karst.) in Loviisa, Southern Finland $\left(60^{\circ} 27^{\prime} 25^{\prime \prime} \mathrm{N}, 26^{\circ} 13^{\prime}\right.$ $\left.30^{\prime \prime} \mathrm{E}\right)$. The first area was Myrtillus type forest (Cajander 1926) on coarse moraine soil, 4.7 ha in size and cut in 2012. The second one was Oxalis-Myrtillus type forest on fine moraine, 2.1 ha in size and cut in 2010. At both sites, broadleaved saplings were cut and soil prepared (mounding) in 2013, and spruce seedlings 1-2 years old were planted in 2014. By 2017, a dense cover of naturally regenerated birch (Betula pendula Roth and Betula pubescens Ehrh.) saplings had regrown at both sites.

Altogether, 640 birch (B. pendula and B. pubescens) saplings were included in the study (Table 1). B. pendula and $B$. pubescens were not investigated separately since their responses to the $C$. purpureum treatment do not differ significantly from each other (Hamberg et al. 2015). The saplings were marked with a tag and a plastic stick. Four different treatments were performed at both sites: (1) saplings were cut with a clearing saw and a suspension of $C$. purpureum inoculum strain R5 (Hamberg et al. 2015, DSMZ 28656) was applied on freshly cut stump surfaces using a plastic pressure sprayer (basal solution was provided by Verdera Ltd., Espoo, Finland, and it included $1.3 \times 10^{6}$ colony forming units (CFU) per g, according to Gonzáles (1996), and was diluted 1:10 with tap water just before the treatment), (2) similar C. purpureum treatment but adjuvant Silwet Gold added (1 g per liter, i.e., $0.1 \%$ of the total weight of inoculum, Berner Ltd., Helsinki, Finland), (3) similar C. purpureum treatment with an adjuvant Polyhydra ( $4.5 \mathrm{~g}$ per liter, i.e., $0.5 \%$ of the total weight of inoculum, DF Green Ltd., Helsinki, Finland), and (4) the control (cutting only, no inoculum). All inoculums were spread on potato dextrose agar Petri plates before and after the treatments to verify their viability (all were viable).

Treatments in the field were performed on the 7th of June 2017. The weather was sunny (no rain) with a mean daily temperature of $16.2{ }^{\circ} \mathrm{C}$ (Natural Resources Institute Finland 2019; a description of the data set from Venäläinen et al. 2005). At each site, birch saplings were treated either under 
Table 1 The number of investigated birch (Betula pendula and Betula pubescens) stumps and their diameter, height, and growth space (number of other saplings around) in different treatments where the fungus
Chondrostereum purpureum was used as a control agent of sprouting, and fungus-free control

\begin{tabular}{|c|c|c|c|c|c|c|}
\hline Condition & Treatment & Number of saplings & $\begin{array}{l}\text { Amount of irrigation } \\
\left(\mathrm{mm} \mathrm{m}^{-2}\right)^{\mathrm{a}}\end{array}$ & Stump diameter $(\mathrm{cm})$ & Stump height $(\mathrm{cm})$ & $\begin{array}{l}\text { Number of other } \\
\text { saplings around }\end{array}$ \\
\hline \multirow[t]{4}{*}{ Dry } & C. purpureum & 80 & 0 & $1.4 \pm 0.6$ & $17.5 \pm 3.0$ & $12.3 \pm 5.2$ \\
\hline & C. purpureum + Silwet Gold ${ }^{c}$ & 80 & 0 & $1.3 \pm 0.5$ & $17.5 \pm 3.0$ & $11.6 \pm 4.9$ \\
\hline & C. purpureum + Polyhydra ${ }^{c}$ & 80 & 0 & $1.2 \pm 0.4$ & $16.7 \pm 3.0$ & $12.8 \pm 6.8$ \\
\hline & Control & 80 & 0 & $1.3 \pm 0.5$ & $19.4 \pm 2.9$ & $11.6 \pm 4.7$ \\
\hline \multirow[t]{4}{*}{ Rainstorm } & C. purpureum & 80 & $24 \pm 13$ & $1.4 \pm 0.5$ & $18.2 \pm 3.3$ & $9.6 \pm 3.4$ \\
\hline & C. purpureum + Silwet Gold ${ }^{c}$ & 80 & $18 \pm 11$ & $1.4 \pm 0.4$ & $16.9 \pm 3.0$ & $9.1 \pm 3.1$ \\
\hline & C. purpureum + Polyhydra $^{\mathrm{c}}$ & 80 & $20 \pm 11$ & $1.3 \pm 0.5$ & $18.5 \pm 4.2$ & $8.4 \pm 2.6$ \\
\hline & Control & 80 & $8 \pm 2^{\mathrm{d}}$ & $1.3 \pm 0.5$ & $20.6 \pm 3.9$ & $14.5 \pm 4.4$ \\
\hline
\end{tabular}

Means \pm standard deviations have been presented

${ }^{\mathrm{a}}$ Measured using rain gauge, mean \pm standard deviation per $0.5 \mathrm{~h}$ presented. The criteria for rainstorm is $5.5 \mathrm{~mm} \mathrm{~m}^{-2}$ per $0.5 \mathrm{~h}$ (Finnish Meteorological Institute 2017)

${ }^{\mathrm{b}}$ Number of other saplings and stumps around an investigated stump within a radius of $0.5 \mathrm{~m}$

${ }^{\mathrm{c}}$ Adjuvant

${ }^{\mathrm{d}}$ Windy weather moved water away from the control plots more than from the other treatment plots

artificial rain (two clusters including all treatments) or with no rain (two clusters including all treatments). Each cluster, including all treatments, was irrigated from the middle of the cluster upwards by the Volunteer Fire Department of the municipality of Porlammi for $30 \mathrm{~min}: 15 \mathrm{~min}$ during the cutting and treatment of stumps and $15 \mathrm{~min}$ after that. The amount of irrigation was adjusted to correspond to a rainstorm, i.e., at least $5.5 \mathrm{~mm} \mathrm{~m}^{-2}$ per $0.5 \mathrm{~h}$ (Finnish Meteorological Institute 2017), and it was measured within each of the clusters treated under artificial rain using a rain gauge (model Tarmo, EAN: 6410412539328). In each irrigation cluster including all treatments, we started with a different treatment (in the first cluster with the first treatment, i.e., C. purpureum only; in the second cluster with the second treatment, etc.) and other treatments were performed in the same order as presented above. The same order of treatments was followed also in the other four blocks without artificial rain. A buffer zone of at least $4 \mathrm{~m}$ was used around the sample plots, and all of the saplings were cut between them. Stumps in treatments without artificial rain were covered by a plastic shelter that was supported by a wooden framework (forming a triangular tent open at both ends) for 5 days to ensure that natural rains did not affect the results. During these 5 days, i.e., 7 th to 12 th of June 2017, the mean maximum temperature was $19.8^{\circ} \mathrm{C}$ (Natural Resources Institute Finland 2019; Venäläinen et al. 2005). We did not measure maximum temperature within the tents but based on earlier research, it may have been up to twice as high as the temperature outside the tents (Pinomaa 2016). During these 5 days when the tents were within the two regeneration areas, we measured the amount of rain using four rain gauges (model Tarmo, EAN: 6410412539328). Two rain gauges were located in each forest regeneration area, one next to a tent and the other located next to a cluster including sample plots treated under artificial rain. When the tents were removed on the 12th of June, it had rained $20-21 \mathrm{~mm} \mathrm{~m}^{-2}$ based on rain gauges (according to weather records $29 \mathrm{~mm} \mathrm{~m}^{-2}$, Natural Resources Institute Finland 2019; Venäläinen et al. 2005), and all shelters were intact, i.e., with no leakage of rainwater.

Saplings were investigated in September 2017, 2018, and 2019. In 2017, one growing season after the treatments ( 3 months), we measured the diameter $(\mathrm{mm})$ and the height of the stumps (from the base to the cut surface, $\mathrm{cm}$ ), and counted the number of other saplings and stumps around an investigated stump $(r=0.5 \mathrm{~m})$. Furthermore, in 2017, 2018, and 2019, we counted the number of living stump sprouts, measured the height of the tallest stump sprout per stump (cm), and counted the number of fruiting bodies of C. purpureum per stump (as a class: $0=$ no fruiting bodies, $1=1-3$ fruiting bodies, $2=4-10$ fruiting bodies, $3=$ more than 10 fruiting bodies). Traces of hare or moose browsing were also recorded ( $0=$ no browsing, $1=$ browsing observed).

Wood samples were randomly taken from 160 stumps (5 per sample plot) on October 16-17 in 2017 to investigate whether $C$. purpureum had penetrated to treated stumps. On these days, weather was cloudy with a temperature of ca. $9{ }^{\circ} \mathrm{C}$ and very slight rain (ca. $3 \mathrm{~mm}$, Natural Resources Institute Finland 2019; Venäläinen et al. 2005). All equipment, knife, drill bit, and cut plastic bottle (collector) for collecting wood chips, were sterilized with diethyl ether (VWR International Ltd., Helsinki, Finland) before sampling from each stump. First, bark was removed from the upper parts of stumps (from one side), ca. $1-5 \mathrm{~cm}$ from the cut surface downwards, with a 
sterilized knife, and the fresh wood was surface sterilized with ether. Second, samples were drilled from the sterilized area with a sterilized $4-5 \mathrm{~mm}$ drill bit; wood chips (ca. $0.28 \mathrm{~g}$ per sample) were collected in a sterilized plastic container and moved to small labelled paper bags, with one sample per bag. Third, the holes created by drilling were covered with a protective agent (Cooper Bio Haavasuoja, Berner Ltd., Helsinki, Finland) to improve wound recovery from drilling in order to minimize penetration of other pathogens.

\section{Investigations in the laboratory}

Ca. $0.02 \mathrm{~g}$ of fresh wood chips were extracted for fungal DNA from stump samples (Nucleo Spin® Soil, Macherey-Nagel Inc., Düren, Germany) in order to verify the presence of C. purpureum strain R5 in treated stumps. Master mix, $25 \mu \mathrm{l}$, was prepared as follows: $20.4 \mu \mathrm{lDDW}, 2.5 \mu \mathrm{l}$ Dream $\mathrm{Taq}^{\mathrm{TM}}$ buffer (Thermo Scientific ${ }^{\mathrm{TM}}$, Vantaa, Finland), $0.5 \mu \mathrm{l}$ dNTP $(10 \mu \mathrm{M}), 0.5 \mu \mathrm{l}$ forward primer $(25 \mu \mathrm{M}), 0.5 \mu$ l reverse primer $(25 \mu \mathrm{M}), 0.1 \mu \mathrm{l}$ DreamTaq DNA polymerase (Thermo Scientific ${ }^{\mathrm{TM}}$, Vantaa, Finland), and $0.5 \mu \mathrm{l}$ of DNA sample. Four pairs of primers with increased specificity to C. purpureum strain R5 were used in PCR analyses (Hamberg et al. 2017). To verify the PCR result, ca. $11 \%$ of the samples were investigated again, starting from wood chips. For the rest of the samples, only PCR was performed twice, and in the cases that the amplification was inefficient (only a faint band in a gel) in the first round, the amount of template was doubled.

Furthermore, three wood chips were placed on water agar in order to cultivate the inoculated C. purpureum strain R5 from them. In case a hypha of $C$. purpureum was growing out of the chip, a single hyphal tip was moved onto Potato Dextrose agar (PDA: $24 \mathrm{~g}$ potato dextrose broth and $15 \mathrm{~g}$ agar with $1000 \mathrm{ml}$ deionized water; Becton, Dickinson and Company, Franklin Lakes, NJ, USA). After hyphal growth, a piece from the mycelial edge was moved onto PDA agar covered with cellophane agar. After the hypha was grown on a cellophane PDA, a piece of ca. $2 \mathrm{~mm}^{2}$ was moved to a tube for DNA extraction (Vainio et al. 1998). The success of DNA extraction was verified by PCR with a RAMS (Random Amplified Microsatellites) or a minisatellite M13 primer as described by Hamberg et al. (2017): $19.4 \mu \mathrm{l}$ DDW, $2.5 \mu \mathrm{l}$ DreamTaq buffer, $0.5 \mu \mathrm{l}$ dNTP, $2 \mu 1$ primer, $0.1 \mu 1$ DreamTaq polymerase, and $0.5 \mu$ DNA sample. DNA concentration was determined with NanoDrop, and samples were diluted 1:10 when the concentration was less than $10 \mathrm{ng}^{-1} \mathrm{l}^{-1}$,

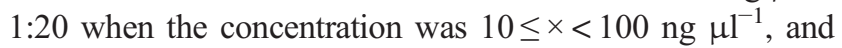
$1: 100$ when it was $\geq 100 \mathrm{ng}_{\mu \mathrm{l}^{-1}}$.

C. purpureum strain R5 specific primers were used to test whether the hyphae originated from the strain R5. Master mix (AllTaq Master Mix Kit, Qiagen Group, Helsinki, Finland) was used in $20 \mu \mathrm{l}$ PCR reactions as follows: $5 \mu \mathrm{l}$ Master
Mix (including enzyme, buffer, and dNTP), $14.5 \mu 1$ DDW, $0.2 \mu \mathrm{l}$ forward primer $(25 \mu \mathrm{M}), 0.2 \mu \mathrm{l}$ reverse primer $(25 \mu \mathrm{M})$, and $0.1 \mu \mathrm{l}$ DNA sample. PCR conditions were modified from Hamberg et al. (2017): (1) $95{ }^{\circ} \mathrm{C}$ for $2 \mathrm{~min}$, (2) $95^{\circ} \mathrm{C}$ for $5 \mathrm{~s}$, (3) $57 / 59^{\circ} \mathrm{C}$ for $15 \mathrm{~s}$, (4) $72{ }^{\circ} \mathrm{C}$ for $10 \mathrm{~s}$, and (5) cooling to $4{ }^{\circ} \mathrm{C}$. Phases $2-4$ were repeated 36 times for the primer pairs R5CGA800F/R and R5CCA1200F/R, 38 times for R5GT600F/R17, and 40 times for R5GTG390F/RUA. All reactions were done twice $(5 \%$ starting from the DNA extraction), and in case a marker was not visible, PCR was performed again with a dilution of 1:10, 1:20, or 1:100. The hypha was considered the $C$. purpureum strain R5 if amplifications with all four R5 specific primer pairs resulted in amplification products.

\section{Statistical analyses}

Effects of the treatment conditions (dry weather and artificial rainstorm) on the mortality of birch stumps (i.e., no living stump sprouts) were investigated with generalized linear mixed models (GLMMs) in the statistical program R, in library lme4, using function glmer, and binomial distribution with logit link (Bates et al. 2015; R Core Team 2018). All stumps were included in these models. The effects on the number of stump sprouts per stump were investigated using glmer function assuming Poisson distribution with log link, and on the maximum height of stump sprouts assuming normal distribution (with identity link) in library nlme using function lme after the response was log transformed (Pinheiro et al. 2018). In stump sprout models (number and maximum height), only living stumps, having at least one sprout, were included. Data for each treatment, i.e., for (1) C. purpureum, (2) C. purpureum with an adjuvant Silwet Gold, (3) C. purpureum with an adjuvant Polyhydra, and (4) control, were analyzed separately.

Each model included explanatory variables as follows: (1) interaction between condition (a factor with two levels: dry weather or artificial rainstorm) and year (a factor with three levels: 2017, 2018, and 2019), (2) diameter of a stump (mm), (3) height of a stump (cm), (4) the number of other stumps and saplings around an investigated stump, and (5) a factor with two levels indicating whether a wood sample had been taken from a stump $(0=$ not drilled, $1=$ wood sample drilled from a stump). Furthermore, a factor indicating whether hare or moose browsing was visible $(0=$ no browsing, $1=$ browsing observed) was added to the maximum height of stump sprout models. Explanatory variables 2-4 (and browsing for the maximum height models) were included in the models because these may have an effect on the mortality, on the number of, or on the maximum height of stump sprouts (Hamberg et al. 2015). Furthermore, because drilling may increase mortality and affect the ability of a stump to produce stump sprouts, we separated it from the effects of the treatment 
condition (dry vs. rainstorm). Site and cluster (including four different treatments) were included in the models as nested random factors since stumps and sample plots within a site may be more similar than randomly collected birch stumps. All figures in the "Results" section have been drawn using R and are presented using predictions based on the models $(\mathrm{R}$ Core Team 2018).

\section{Results}

The DNA of the C. purpureum strain R5 was frequently amplified with direct amplification from the wood of the treated birch (B. pendula and B. pubescens) stumps but never from the control stumps (Table 2). The frequencies were relatively similar on stumps subjected to rainy and dry conditions. C. purpureum grew also from wood chips drilled from stumps that were infected with the fungal strain R5, 83 times, i.e., ca. $52 \%$ of the wood samples collected $(n=160)$, verifying Koch's postulates. Almost all fungal strains grown from wooden samples were proven to be $C$. purpureum strain R5 used for inoculations, showing that the fungus had successfully penetrated the stumps, both cut and treated (Table 2). Only in a few cases, the detected $C$. purpureum was another strain than R5. Fungal strains grew also from two control stumps, but none of them was identified as strain R5.

One growing season after the treatments (i.e., after 3 months), mortality of birch stumps was lower in stumps treated with $C$. purpureum under artificial rain compared with stumps treated in dry conditions ( $p \leq 0.001$, Table 3, Fig. 1). However, in the pure $C$. purpureum treatment without adjuvants, the mortality of birch stumps treated under artificial rain increased considerably quicker (from $4 \%$ in 2017 to $74 \%$ in 2019 ) than in dry condition (from 39 to $86 \%, p<0.004$ ) so that by the end of the experiment (2019) there was no statistically significant difference between treatments conducted under artificial rain and in dry conditions. In the C. purpureum treatments with adjuvants (both Silwet Gold and Polyhydra) performed under artificial rain, the mortality increased from 4-6\% up to 58-67\% in 2017-2019 and stayed at lower levels than in the treatments performed in dry weather (increase from $30-45 \%$ up to $88-91 \%$ in years $2017-2019$, the curves for dry and artificial rain did not differ, $p \geq 0.177$, see Table 3, Fig. 1). In the control (cutting only, no C. purpureum application on birch stumps), stump mortality increased from the first inventory in 2017 to the last in 2019 similarly both in artificial rain (from 3 to $19 \%$ ) and dry conditions (6 to $17 \%, p \geq 0.289$ ).

The number of stump sprouts per living stump decreased from the first inventory in 2017 to the last inventory in 2019 similarly both in rainstorm and dry conditions in all treatments and the control $(p \geq 0.068)$, except in the C. purpureum treatment with the adjuvant Silwet Gold $(p=0.021$, Table 3, Fig. 2). In this treatment, the number of stump sprouts per stump decreased more slowly in stumps treated under artificial rain than in stumps treated without artificial rain.

In all $C$. purpureum treatments, the maximum height of stump sprouts increased from the first inventory in 2017 to the last inventory in 2019 similarly in stumps treated under artificial rain and in dry conditions ( $p \geq 0.107$, Table 3, Fig. 3). However, in the control treatment without $C$. purpureum, sprouts grew faster after cutting under artificial rain $(p=$ $0.035)$.

Larger stumps (in terms of stump diameter) died faster than smaller stumps in all C. purpureum treatments (GLMMs, $p \leq$ 0.001 for all). However, in the control treatment (cutting only), living larger stumps yielded more sprouts $(p<0.001)$, and in the $C$. purpureum treatment with the adjuvant Silwet Gold and the control, they yielded taller stump sprouts $(p=0.050$ and $p=0.007$, respectively) than smaller stumps. In the

Table 2 Frequency of the decay fungus Chondrostereum purpureum, strain R5, used in the study, on birch, Betula pendula and Betula pubescens, stumps ca. 4 months after the treatments

\begin{tabular}{|c|c|c|c|c|c|}
\hline \multirow[t]{2}{*}{ Condition } & \multirow[t]{2}{*}{ Treatment } & \multicolumn{4}{|c|}{ Frequency $(\%)$} \\
\hline & & $n$ & Directly from wood samples & $n$ & $\begin{array}{l}\text { From fungal hypha grown } \mathrm{f} \\
\text { rom wooden chips }\end{array}$ \\
\hline \multirow[t]{4}{*}{ Dry } & C. purpureum & 20 & 100 & 14 & 100 \\
\hline & C. purpureum + Silwet Gold ${ }^{\mathrm{a}}$ & 20 & $90 \pm 7$ & 16 & $88 \pm 9$ \\
\hline & C. purpureum + Polyhydra ${ }^{\mathrm{a}}$ & 20 & 100 & 12 & 100 \\
\hline & Control & 20 & 0 & 0 & - \\
\hline \multirow[t]{4}{*}{ Rainstorm } & C. purpureum & 20 & 100 & 11 & 100 \\
\hline & C. purpureum + Silwet Gold ${ }^{\mathrm{a}}$ & 20 & $85 \pm 8$ & 14 & 100 \\
\hline & C. purpureum + Polyhydra ${ }^{\mathrm{a}}$ & 20 & $75 \pm 10$ & 14 & $93 \pm 7$ \\
\hline & Control & 20 & 0 & 2 & 0 \\
\hline
\end{tabular}

The occurrence was verified by PCR using R5 specific primers (see Hamberg et al. 2017). Means \pm standard errors have been presented

${ }^{\text {a Adjuvant }}$ 


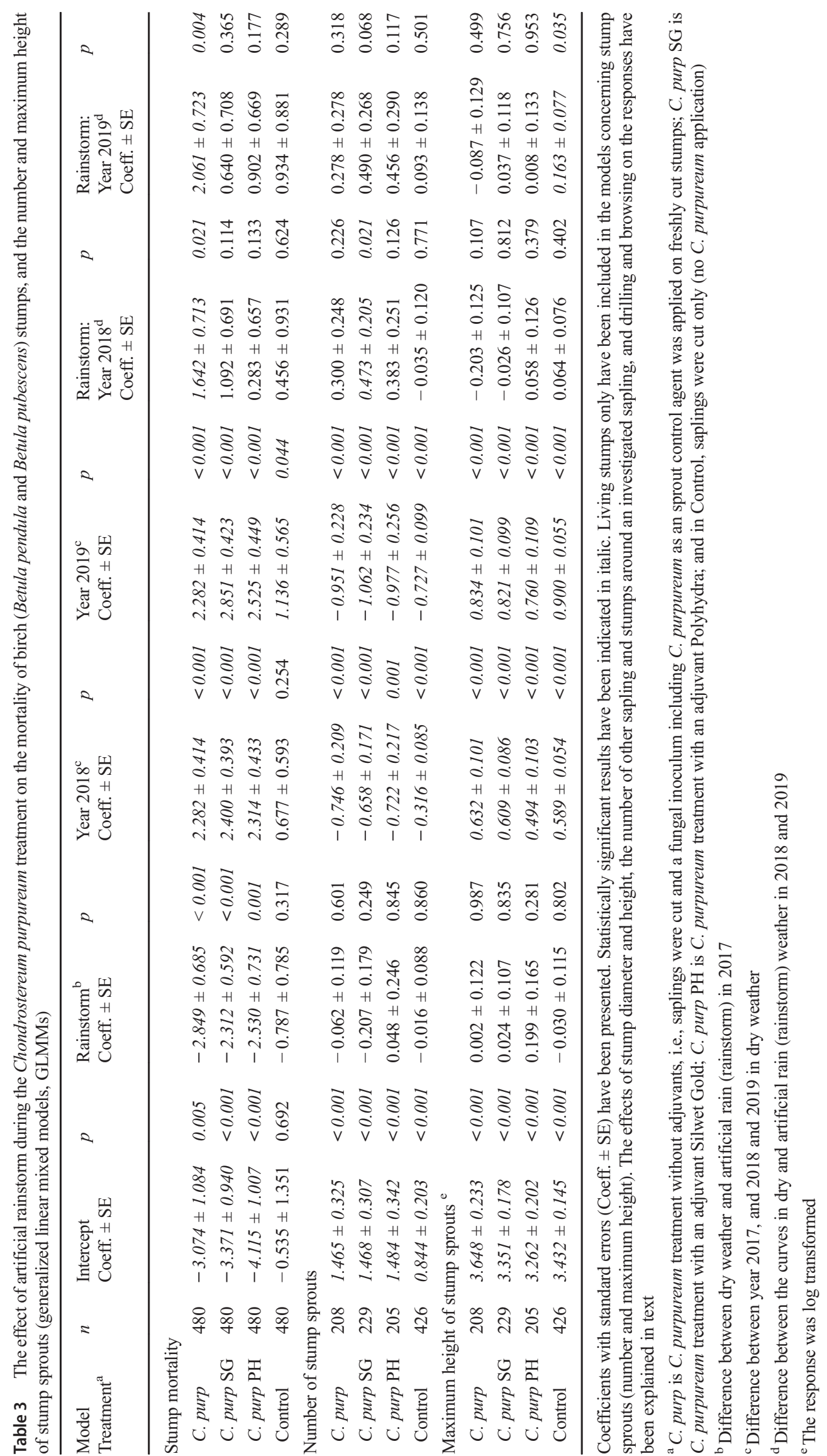


Fig. 1 Predicted values for birch (Betula pendula and Betula pubescens) stump mortality based on the GLMMs (Table 3 ) for a the Chondrostereum purpureum treatment $(n=480), \mathbf{b}$ the $C$. purpureum with the adjuvant Silwet Gold treatment (SG, $n=$ 480 ), $\mathbf{c}$ the $C$. purpureum with the adjuvant Polyhydra treatment (PH, $n=480$ ), and for $\mathbf{d}$ the control (no C. purpureum application on stump surfaces, $n=480$ ) when the treatments have been performed under artificial rainstorm (rain) or without it (dry). Predictions for one (2017), two (2018), and three (2019) growing seasons after the treatments have been counted using mean values for stump diameter, stump height, and other saplings and stumps around an investigated stump, and assuming no drilling
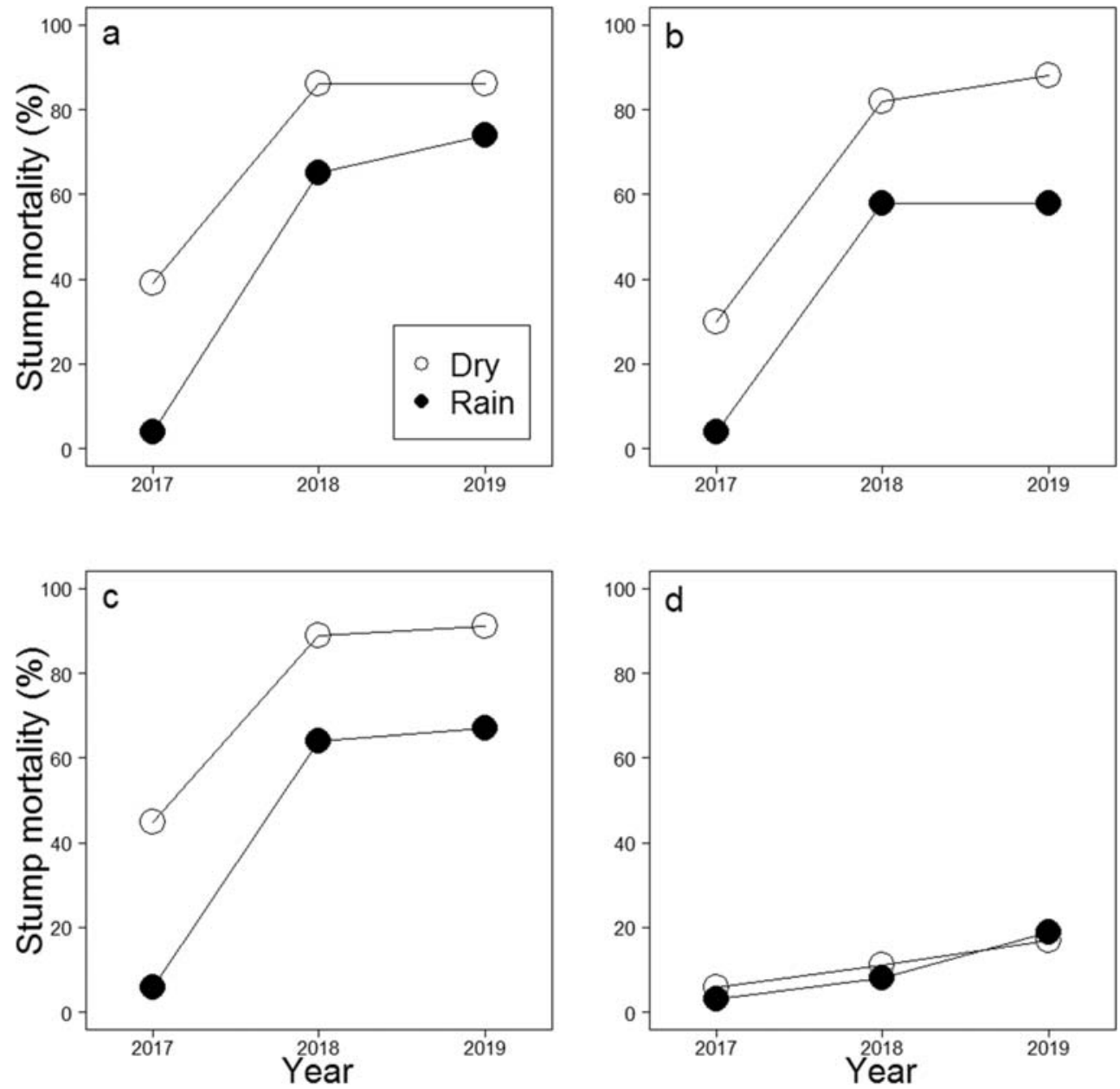

control, stump mortality was lower $(p=0.003)$ and the number of stump sprouts per stump was higher $(p=0.042)$ in taller than shorter stumps. In the $C$. purpureum treatment with the adjuvant Polyhydra, the number of stump sprouts decreased with increasing number of other saplings and stumps around an investigated stump $(p=0.050)$. Drilling did not affect stump mortality. In the $C$. purpureum treatment with the adjuvant Silwet Gold, the maximum height of stump sprouts was higher in drilled than in non-drilled stumps $(p=0.024)$ but in the $C$. purpureum treatment with the adjuvant Polyhydra, the maximum height of stump sprouts was lower in drilled than in non-drilled stumps $(p=0.035)$. Browsing did not affect the maximum height of birch stump sprouts in different treatments.

In C. purpureum treatments, fruiting bodies were most frequent after the second growing season (Table 4). It seems that development of fruiting bodies was slightly delayed after treatments performed under artificial rainstorms, since after the third growing season, they were more abundant than in stumps treated in the dry condition. In the control (cutting only), the occurrence of fruiting bodies was low.

\section{Discussion}

Our results revealed that heavy rain caused delays in the efficacy of the $C$. purpureum treatment against sprouting of birch (B. pendula and B. pubescens). However, in the pure $C$. purpureum treatment, this effect was only temporary since three growing seasons after the treatment there was no significant difference in stump mortalities when stumps were treated under heavy irrigation or without it. This agrees with previous studies, where natural (slight) rain has caused only temporal (Hamberg and Hantula 2020) or insignificant effects (Vartiamäki et al. 2009) on the efficacy of C. purpureum in preventing stump sprouting. These minor effects have possibly been due to a better moisture level for $C$. purpureum to grow (Boddy 1983a, b), but the delay observed here was probably caused by a rinsing of fungal mycelium from the stump surface under the heavy irrigation. This was also supported by the fact that in the treatments under heavy rain, fruiting bodies still occurred three growing seasons after the treatments, unlike in the treatments performed in dry conditions: fruiting bodies are known to occur for a longer time in 
Fig. 2 Predicted values for the number of birch (Betula pendula and Betula pubescens) stump sprouts per living stump based on the GLMMs (Table 3) for a the Chondrostereum purpureum treatment $(n=208)$, b the

$C$. purpureum with the adjuvant Silwet Gold treatment (SG, $n=$ 229), c the C. purpureum with the adjuvant Polyhydra treatment ( $\mathrm{PH}, n=205$ ), and for $\mathbf{d}$ the control (no C. purpureum application on stump surfaces, $n=426$ ) when the treatments have been performed under artificial rainstorm (rain) or without it (dry). Predictions for one (2017), two (2018), and three (2019) growing seasons after the treatments have been counted using mean values for stump diameter, stump height, and other saplings and stumps around an investigated stump, and assuming no drilling
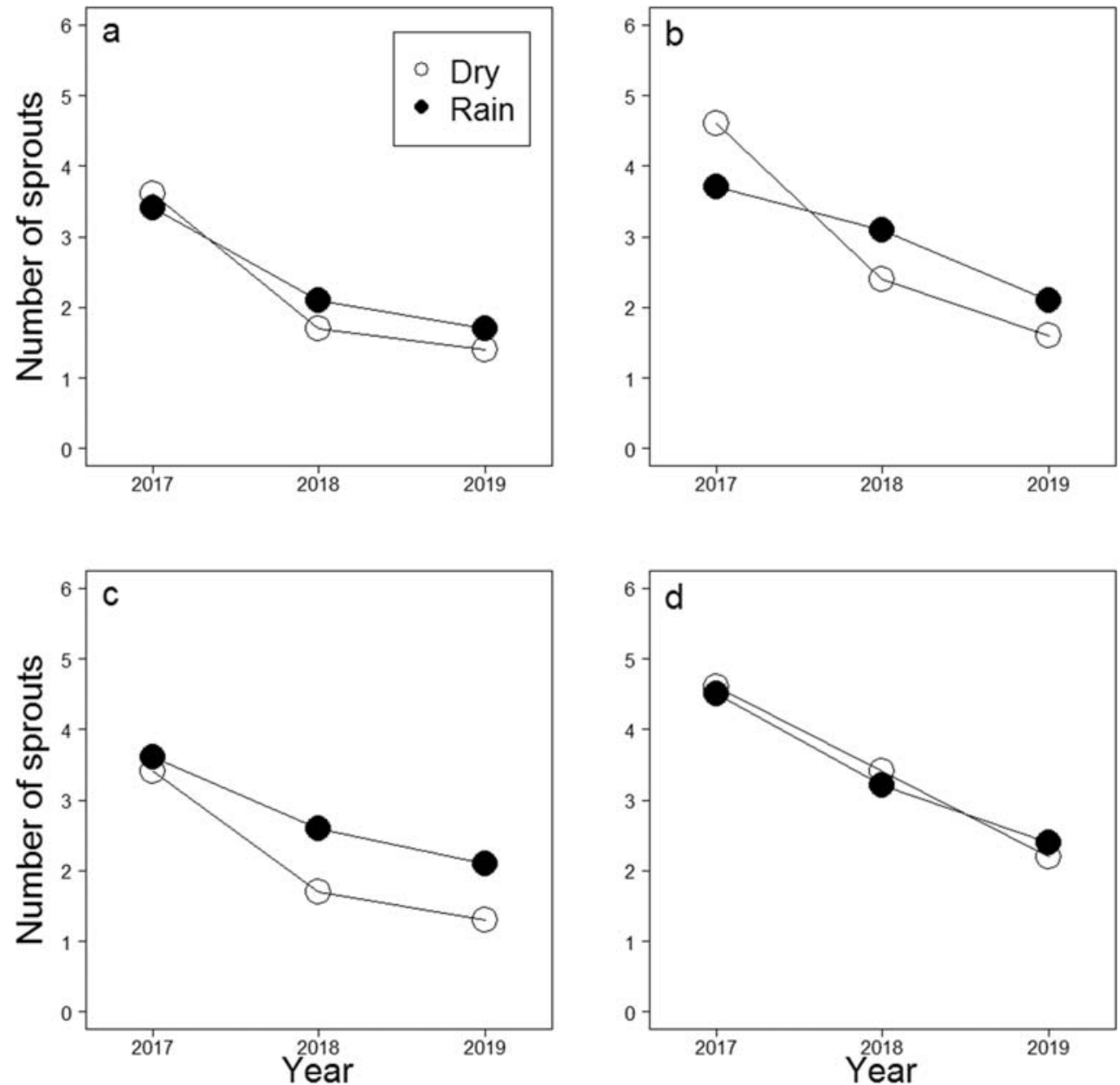

trees that die slowly (Wall 1997). Thus, in possible practical applications, the number of colony-forming units should be high enough in fungal inoculum so that at least some hyphal fragments will stay on stump surfaces after heavy rain until they have grown into the wood. No clear differences between the three different $C$. purpureum treatments were found in dry weather, as all $C$. purpureum treatments yielded more than $80 \%$ mortalities corresponding to earlier results with birch (B. pendula and B. pubescens) saplings (Hamberg and Hantula 2018; Hamberg et al. 2015; Vartiamäki et al. 2009).

Unfortunately, adjuvants which aimed to help the spray adhere better seemed inefficient, since mortalities in the treatments under artificial rain remained at a lower level than in the treatments in dry conditions. This was disappointing as in fruit plants, the use of adjuvants has been proven to improve cell adherence and persistence of biological control agents on plant tissues (Calvo-Garrido et al. 2019; Larena et al. 2010). Similarly, adjuvants also greatly improved the biological control potential of the fungus, Colletotrichum gloeosporioides (Penz.) Penz \& Sacc. against sicklepod, Senna obtusifolia (L.) Irwin \& Barnaby, which is a serious weed pest in the southeastern US (Boyette 2006). The adjuvants tested in the present study should be further developed before their application to increase the efficacy of biological sprout control under rainy conditions can be considered.

The number and maximum height of stump sprouts did not differ between the $C$. purpureum treatments, but the general feature was that the number of stump sprouts decreased whereas the maximum height of stump sprouts increased from year 2017 to 2019 (see also Laine et al. 2019a). In the control, it seemed that the number and maximum height of stump sprouts was slightly higher - but not significantly differentthan in the fungal treatments, which agrees with the results of previous research (Hamberg et al. 2015).

In this study, stump mortality was higher in stumps with larger diameters than in smaller stumps (similarly as in Hamberg et al. 2014; Laine et al. 2019b). Possibly, the larger stump surface enables fungal fragments to reach it more easily, and definitely, there is more space for a higher number of fungal fragments to colonize it. In large living stumps, the number and maximum height of stump sprouts was higher than in smaller stumps, possibly due to the better resources in the larger root systems of these plants (Aosaar et al. 2013; Laine et al. 2019a, b). Similarly, increase in competition (more 
Fig. 3 Predicted values for the maximum height of birch (Betula pendula and Betula pubescens) stump sprouts based on the GLMMs (Table 3) for a the Chondrostereum purpureum treatment $(n=208), \mathbf{b}$ the C. purpureum with the adjuvant Silwet Gold treatment SG, $n=$ 229), c the C. purpureum with the adjuvant Polyhydra treatment (PH, $n=205)$, and for $\mathbf{d}$ the control (no C. purpureum application on stump surfaces, $n=426$ ) when the treatments have been performed under artificial rainstorm (rain) or without it (dry). Predictions one (2017), two (2018), and three (2019) growing seasons after the treatments have been counted using mean values for stump diameter, stump height, and other saplings and stumps around an investigated stump, and assuming no drilling and browsing
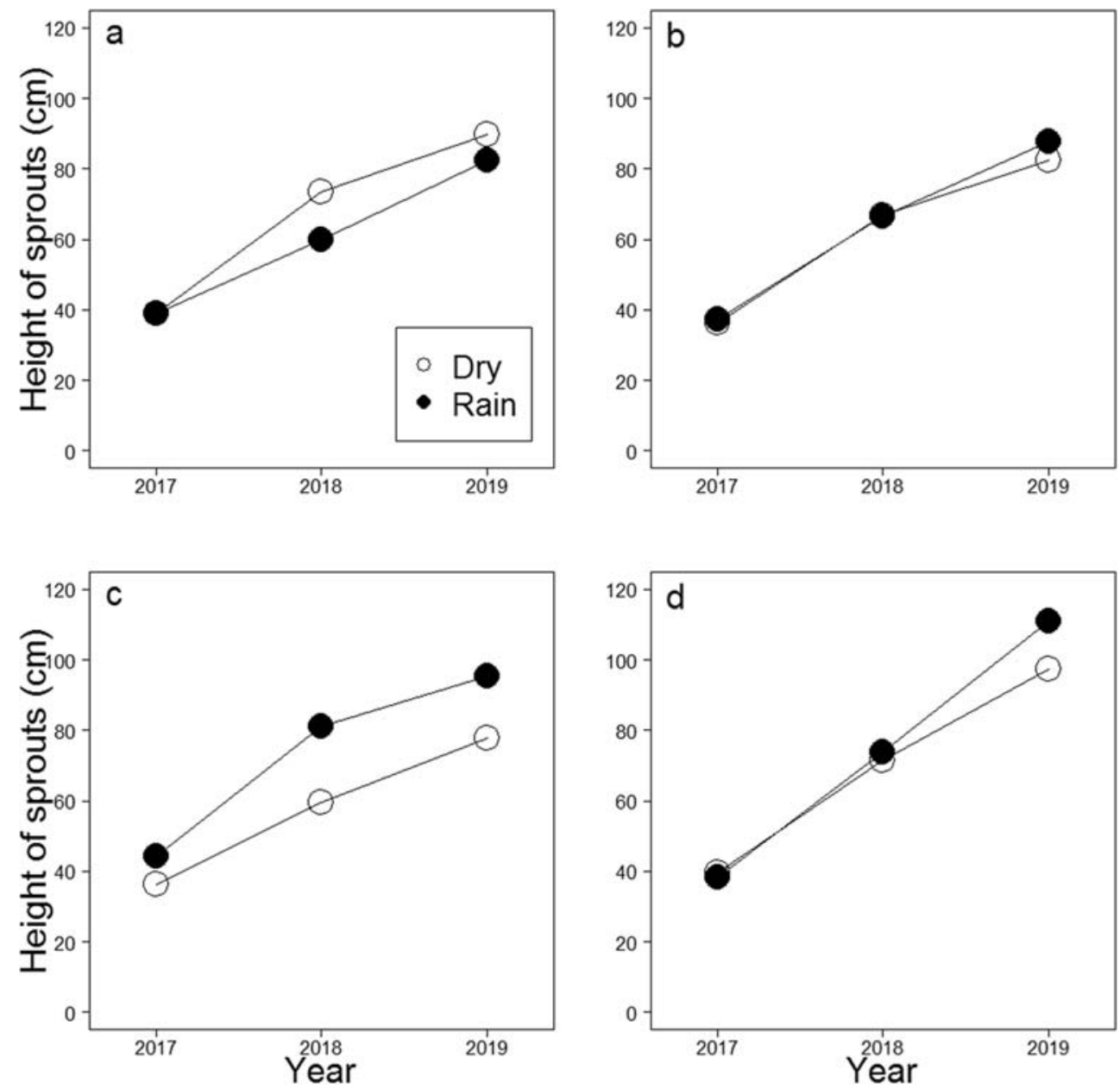

saplings and stumps) around an investigated sapling was associated with lower number of stump sprouts indicating that limited resources within an area decreases the possibilities for the recovery of single plants (see also Atkinson 1992; Hamberg and Hantula 2018; Jones and Harper 1987; Laine et al. 2019a, b). Furthermore, lower stump mortality and

Table 4 Occurrence of fruiting bodies of the decay fungus Chondrostereum purpureum on birch, Betula pendula and Betula pubescens, stumps in the different treatments and conditions one, two, and three growing seasons after the treatments in 2017, 2018, and 2019

\begin{tabular}{|c|c|c|c|c|c|c|c|}
\hline \multirow[t]{2}{*}{ Condition } & \multirow[t]{2}{*}{ Treatment } & \multicolumn{6}{|c|}{ Occurrence $(\%)$} \\
\hline & & $n$ & After the first growing season & $n$ & $\begin{array}{l}\text { After the second } \\
\text { growing season }\end{array}$ & $n$ & $\begin{array}{l}\text { After the third } \\
\text { growing season }\end{array}$ \\
\hline \multirow[t]{4}{*}{ Dry } & C. purpureum & 80 & $16 \pm 4$ & 80 & $50 \pm 6$ & 80 & 0 \\
\hline & C. purpureum + Silwet Gold ${ }^{\mathrm{a}}$ & 80 & $9 \pm 3$ & 80 & $56 \pm 6$ & 80 & $4 \pm 2$ \\
\hline & C. purpureum + Polyhydra $^{\mathrm{a}}$ & 80 & $15 \pm 4$ & 80 & $58 \pm 6$ & 80 & 0 \\
\hline & Control & 80 & 0 & 80 & $1 \pm 1$ & 80 & 0 \\
\hline \multirow[t]{4}{*}{ Rainstorm } & C. purpureum & 80 & $8 \pm 3$ & 80 & $60 \pm 6$ & 80 & $10 \pm 3$ \\
\hline & C. purpureum + Silwet Gold ${ }^{\mathrm{a}}$ & 80 & $4 \pm 2$ & 80 & $51 \pm 6$ & 80 & $4 \pm 2$ \\
\hline & C. purpureum + Polyhydra ${ }^{\mathrm{a}}$ & 80 & $6 \pm 3$ & 80 & $54 \pm 6$ & 80 & $8 \pm 3$ \\
\hline & Control & 80 & 0 & 80 & $4 \pm 2$ & 80 & $1 \pm 1$ \\
\hline
\end{tabular}

Means \pm standard errors have been presented

${ }^{\text {a }}$ Adjuvant 
higher sprout number per stump was associated with taller stumps. This highlights the fact that it is important not to leave tall stumps during cutting.

In our experiment, diethyl ether was used to sterilize drill bits and other equipment between the samplings. Based on our observations and results, it seemed that this method is relatively good: no cross-contamination was observed between the control and the $C$. purpureum treatments since C. purpureum hyphae grew only from two control stumps but none of the hyphae belonged to the applied fungal strain R5. Furthermore, ether is relatively easy to use in the field since it evaporates quickly so that there is no need for long waiting times between different samples. Yet, more research is needed to verify that ether can be used in sampling of environmental DNA, where cross-contamination may occur even from dead tissues, although in this, study direct DNA extraction from wood chips yielded highly similar results as the more time-consuming cultivation of fungal hyphae from wood chips followed by isolations of single hyphae and DNA extraction from a mycelial culture.

Acknowledgments Volunteer Fire Department of the municipality of Porlammi is acknowledged for performing an artificial rainstorm in the field. We thank also Kaarina Pynnönen, Janne Siipilehto, and Erkki Piiroinen for help in the field, and Tuija Hytönen, Sirpa Tiikkainen, Minna Oksanen, Janne Siipilehto, and Laura Mikkonen for help in the laboratory. Language was checked by Heikki Kiheri.

Author contribution LH, V-MS, MR, and JH conceived and designed the research. LH, V-MS, and MR conducted experiments. PS developed formulations, provided adjuvants, and planned their concentrations for formulations. LH analyzed data. LH, JH and TS wrote the manuscript. All authors read and approved the manuscript.

Funding information Open access funding provided by Natural Resources Institute Finland (LUKE). The study was funded by the Natural Resources Institute Finland (project number 41007-00096400). This work was also supported by the EU, through the EFFORTE (Efficient forestry by precision planning and management for sustainable environment and cost competitive bio-based industry) project (grant agreement number: 720712 - EFFORTE - H2020-BBI-PPP-201502/H2020-BBI-PPP-2015-2-1).

\section{Compliance with ethical standards}

Ethical approval This article does not contain any studies with human participants or animals performed by any of the authors.

Conflict of interest The authors declare that they have no conflict of interest.

Open Access This article is licensed under a Creative Commons Attribution 4.0 International License, which permits use, sharing, adaptation, distribution and reproduction in any medium or format, as long as you give appropriate credit to the original author(s) and the source, provide a link to the Creative Commons licence, and indicate if changes were made. The images or other third party material in this article are included in the article's Creative Commons licence, unless indicated otherwise in a credit line to the material. If material is not included in the article's
Creative Commons licence and your intended use is not permitted by statutory regulation or exceeds the permitted use, you will need to obtain permission directly from the copyright holder. To view a copy of this licence, visit http://creativecommons.org/licenses/by/4.0/.

\section{References}

Aosaar J, Varik M, Lõhmus K, Ostonen I, Becker H, Uri V (2013) Longterm study of above- and below-ground biomass production in relation to nitrogen and carbon accumulation dynamics in a grey alder (Alnus incana (L.) Moench) plantation on former agricultural land. Eur J For Res 132:737-749. https://doi.org/10.1007/s10342-0130706-1

Atkinson MD (1992) Betula pendula Roth. (B. verrucosa Ehrh.) and B. pubescens Ehrh. Biological Flora of the British Isles. J Ecol 80: 837-870. https://doi.org/10.2307/2260870

Bates D, Maechler M, Bolker B, Walker S (2015) Fitting linear mixedeffects models using lme4. J Stat Softw 67(1):1-48. https://doi.org/ 10.18637/jss.v067.i01

Becker E, Shamoun SF, Hintz WE (2005) Efficacy and environmental fate of Chondrostereum purpureum used as a biocontrol for red alder (Alnus rubra). Biol Control 33:269-277. https://doi.org/10.1016/j. biocontrol.2005.02.013

Bellgard SE, Johnson VW, Than DJ, Anand N, Winks CJ, Ezeta G, Dodd SL (2014) Use of the silverleaf fungus Chondrostereum purpureum for biological control of stump-sprouting, riparian weedy tree species in New Zealand. Australas Plant Pathol 43:321-326. https://doi. org/10.1007/s13313-014-0273-Z

Boddy L (1983a) Carbon dioxide release from decomposing wood: effect of water content and temperature. Soil Biol Biochem 15:501-510. https://doi.org/10.1016/0038-0717(83)90042-1

Boddy L (1983b) Effect of temperature and water potential on growth rate of woodrotting basidiomycetes. Trans Br Mycol Soc 80:141-149. https://doi.org/10.1016/S0007-1536(83)80175-2

Boyette CD (2006) Adjuvants enhance the biological control potential of an isolate of Colletotrichum gloeosporioides for biological control of sicklepod (Senna obtusifolia). Biocontrol Sci Tech 16(10):10571066. https://doi.org/10.1080/09583150600828692

Butler EJ, Jones SG (1949) Silver leaf disease of plum, Stereum purpureum (Fr.) Fr. In: Plant pathology. MacMillian \& Co., London, pp 763-767

Cajander AK (1926) The theory of forest types. Acta For Fenn 29(3). 108 p). https://doi.org/10.14214/aff.7193

Calvo-Garrido C, Roudet J, Aveline N, Davidou L, Dupin S, Fermaud M (2019) Microbial antagonism toward Botrytis bunch rot of grapes in multiple field tests using one Bacillus ginsengihumi strain and formulated biological control products. Front Plant Sci 10:105, 18 p. https://doi.org/10.3389/fpls.2019.00105

de Jong MD (2000) The BioChon story: deployment of Chondrostereum purpureum to suppress stump sprouting in hardwoods. Mycologist 14:58-62. https://doi.org/10.1016/S0269-915X(00)80005-1

Erikson J, Ryvarden L (1973) The Corticiaceae of North Europe, vol 2. Fungiflora, Oslo

Etheridge DE, Morin LA (1963) Colonization by decay fungi of living and dead stems of balsam fir following artificial injury. Can J Bot 41:1532-1534. https://doi.org/10.1139/b63-134

Finnish Meteorological Institute (2017) https://ilmatieteenlaitos.fi/sade. Accessed 27 Apr 2017. (In Finnish)

Gonzáles JM (1996) A general purpose program for obtaining most probable number tables. J Microbiol Methods 26:215-218. https://doi. org/10.1016/0167-7012(96)00818-4 
Gosselin L, Jobidon R, Bernier L (1995) Assessment of genetic variation within Chondrostereum purpureum from Quebec by random amplified polymorphic DNA analysis. Mycol Res 100:151-158. https:// doi.org/10.1016/S0953-7562(96)80113-4

Gosselin L, Jobidon R, Bernier L (1999) Biological control of stump sprouting of broadleaf species in rights-of-away with Chondrostereum purpureum: incidence of the disease on nontarget hosts. Biol Control 16:60-67. https://doi.org/10.1006/bcon.1999. 0736

Hamberg L, Hantula J (2016) The efficacy of six elite isolates of the fungus Chondrostereum purpureum against the sprouting of European aspen. J Environ Manag 171:217-224. https://doi.org/ 10.1016/j.jenvman.2016.02.016

Hamberg L, Hantula J (2018) Tree size as a determinant of recovery of birch (Betula pendula and B. pubescens) and grey alder (Alnus incana) trees after cutting and inoculation with Chondrostereum purpureum. Biol Control 126:83-89. https://doi.org/10.1016/j. biocontrol.2018.07.015

Hamberg L, Hantula J (2020) The biocontrol efficacy of Chondrostereum purpureum is not sensitive to prevailing environmental conditions in boreal forests. For Ecol Manag 456:117646. https://doi.org/10.1016/ j.foreco.2019.117646

Hamberg L, Malmivaara-Lämsä M, Löfström I, Hantula J (2014) Effects of a biocontrol agent Chondrostereum purpureum on sprouting of Sorbus aucuparia and Populus tremula after four growing seasons. BioControl 59:125-137. https://doi.org/10.1007/s10526-013-9550y

Hamberg L, Vartiamäki H, Hantula J (2015) Breeding increases the efficacy of Chondrostereum purpureum in the sprout control of birch. PLoS One 10(2):e0117381. https://doi.org/10.1371/journal.pone. 0117381

Hamberg L, Lemola J, Hantula J (2017) The potential of the decay fungus Chondrostereum purpureum in the biocontrol of broadleaved tree species. Fungal Ecol 30:67-75. https://doi.org/10.1016/j.funeco. 2017.09.001

Harper GJ, Comeau PG, Hintz W, Wall RE, Prasad R, Becker EM (1999) Chondrostereum purpureum as a biological control agent in forest vegetation management. II. Efficacy on Sitka alder and aspen in western Canada. Can J For Res 29:852-858. https://doi.org/10. 1139/x99-121

Jones M, Harper JL (1987) The influence of neighbours on the growth of trees I. The demography of buds in Betula pendula. Proc R Soc Lond B Biol Sci 232:1-18. https://doi.org/10.1098/rspb.1987.0058

Laine T, Hamberg L, Saarinen V-M, Saksa T (2019a) The efficacy of Chondrostereum purpureum against sprouting of deciduous species after mechanized pre-commercial thinning. Silva Fenn 53(3):article id 10195.8 p). https://doi.org/10.14214/sf.10195

Laine T, Hamberg L, Saarinen V-M, Saksa T (2019b) The efficacy of Chondrostereum purpureum in the sprout control of birch during mechanized pre-commercial thinning. BioControl 65(1):13-24. https://doi.org/10.1007/s10526-019-09971-z

Larena I, De Cal A, Melgarejo P (2010) Enhancing the adhesion of Epicoccum nigrum conidia to peach surfaces and its relationship to the biocontrol of brown rot caused by Monilinia laxa. J Appl Microbiol 109:583-593. https://doi.org/10.1111/j.1365-2672.2010. 04681.x

Lygis V, Bakys R, Burokienė D, Vasiliauskaitė I (2012) Chondrostereum purpureum-based control of stump sprouting of seven hardwood species in Lithuania. Baltic For 18:41-55
Natural Resources Institute Finland (2018) Statistical services. Silvicultural and forest improvement work 2018. https://stat.luke. fi/en/silvicultural-and-forest-improvement-work-2018_en. Accessed 15 Nov 2019

Natural Resources Institute Finland (2019) Meteorological Database

Pacanoski Z (2015) Herbicides and adjuvants. In: Price A, Kelton J, Sarunaite L (eds) Herbicides, physiology of action, and safety. IntechOpen, London, pp 125-147. https://doi.org/10.5772/60842

Pinheiro J, Bates D, DebRoy S, Sarkar D, R Core Team (2018) nlme: linear and nonlinear mixed effects models. $\mathrm{R}$ package version 3.1137. https://CRAN.R-project.org/package=nlme

Pinomaa A (2016) Tunnelikasvatuksen vaikutus kesävadelman satoon ja marjan laatuun (yield and quality of floricane fruiting raspberry in protected cultivation). M.Sc. thesis, University of Helsinki (in Finnish with English summary)

R Core Team (2018) R: a language and environment for statistical computing. R Foundation for Statistical Computing, Vienna https:// www.R-project.org/

Ramsfield TD, Becker EM, Rathlef SM, Tang Y, Vrain TC, Shamoun SF, Hintz WE (1996) Geographic variation of Chondrostereum purpureum detected by polymorphisms in the ribosomal DNA. Can J Bot 74:1010-1929. https://doi.org/10.1139/b96-229

Ramsfield TD, Shamoun SF, Punja ZK, Hintz WE (1999) Variation in the mitochondrial DNA of the potential biological control agent Chondrostereum purpureum. Can J Bot 77:1490-1498. https://doi. org/10.1139/b99-125

Uotila K (2017) Optimization of early cleaning and precommercial thinning methods in juvenile stand management of Norway spruce stands. Dissertation, University of Helsinki. Dissertationes Forestales 231. https://doi.org/10.14214/df.231

Vainio EJ, Korhonen K, Hantula J (1998) Genetic variation in Phlebiopsis gigantea as detected with random amplified microsatellite (RAMS) markers. Mycol Res 102:187e192. https://doi.org/10.1017/ S0953756297004577

Vartiamäki H, Uotila A, Vasaitis R, Hantula J (2008) Genetic diversity in Nordic and Baltic populations of Chondrostereum purpureum: a potential herbicide biocontrol agent. For Path 38:381-393. https:// doi.org/10.1111/j.1439-0329.2008.00551.x

Vartiamäki H, Hantula J, Uotila A (2009) Effect of application time on the efficacy of Chondrostereum purpureum treatment against the sprouting of birch in Finland. Can J For Res 39:731-739. https:// doi.org/10.1139/X09-009

Venäläinen A, Tuomenvirta H, Pirinen P, Drebs A (2005) A basic Finnish climate data set 1961-2000. Description and illustrations. Finnish Meteorological Institute, reports no. 2005:5. Edita, Helsinki

Wall RE (1986) Pathogenicity of Chondrostereum purpureum to yellow birch. Plant Dis 70:158-160

Wall RE (1990) The fungus Chondrostereum purpureum as a silvicide to control stump sprouting in hardwoods. North J Appl For 7:17-19. https://doi.org/10.1093/njaf/7.1.17

Wall RE (1991) Pathological effects of Chondrostereum purpureum in inoculated yellow birch and beech. Can J Plant Pathol 13:81-87. https://doi.org/10.1080/07060669109500969

Wall RE (1997) Fructification of Chondrostereum purpureum on hardwoods inoculated for biological control. Can J Plant Pathol 19:181184. https://doi.org/10.1080/07060669709500550

Publisher's note Springer Nature remains neutral with regard to jurisdictional claims in published maps and institutional affiliations. 